\title{
Expression of metabotropic glutamate receptors in the rat and human testis
}

\author{
M Storto ${ }^{1}$, M Sallese ${ }^{2}$, L Salvatore ${ }^{2}$, R Poulet ${ }^{1}$, D F Condorelli ${ }^{3}$, \\ P Dell'Albani $^{4}$, M F Marcello ${ }^{5}, \mathrm{R}^{2}$ Romeo $^{5}$, P Piomboni $^{6}$, \\ N Barone ${ }^{7}$, F Nicoletti $^{1,8}$ and A De Blasi ${ }^{1}$ \\ ${ }^{1}$ INM Neuromed, Pozzilli, Isernia, Italy \\ ${ }^{2}$ Department of Pharmacological Sciences, CMNS, St Maria Imbaro, Chieti, Italy \\ ${ }^{3}$ Department of Chemical Sciences, University of Catania, Italy \\ ${ }^{4}$ IBFSNC-CNR, Catania, Italy \\ ${ }^{5}$ Department of Human Anatomy, University of Catania, Italy \\ ${ }^{6}$ Department for the Study of Germinal Cells, CNR, Siena, Italy \\ ${ }^{7}$ Institute of Internal Medicine, University of Catania, Italy \\ ${ }^{8}$ Department of Human Physiology and Pharmacology, University La Sapienza of Rome, Italy \\ (Requests for offprints should be addressed to F Nicoletti, INM Neuromed, Località Camerelle, 86077 Pozzilli (IS), Italy; \\ Email: neurofarm.nicoletti@neuromed.it)
}

\begin{abstract}
The $G$ protein-coupled receptor kinase type 4 mediates the homologous desensitisation of type-1 metabotropic glutamate (mGlu1) receptors and is predominantly expressed in the testis. Hence, we searched for the expression of mGlu1 or other mGlu receptor subtypes in rat and human testes. RT-PCR analysis showed the presence of mGlu1, -4 and -5 (but not -2 or -3 ) receptor mRNA in the rat testis. The presence of mGlu1 and -5 (but not mGlu2/3) receptor proteins was also demonstrated by Western blot analysis. In the rat testis, both mGlu1a and -5 receptors were highly expressed in cells of the germinal line. It is likely that these receptors are functional, because the agonist, (1S,3R)-1aminocyclopentane-1,3-dicarboxylic acid, was able to stimulate inositol phospholipid hydrolysis in slices pre-
\end{abstract}

pared from rat testes. Immunocytochemical analysis of bioptic samples from human testes showed a high expression of mGlu5 receptors inside the seminiferous tubuli, whereas mGlu1a immunoreactivity was restricted to intertubular spaces. mGlu5 receptors were also present in mature spermatozoa, where they were localised in the mid-piece and tail. This localisation coincided with that of $\beta$-arrestin, a protein that is critically involved in the homologous desensitisation and internalisation of $\mathrm{G}$ protein-coupled receptors. Taken collectively, these results offer the first evidence for the expression of any glutamate receptor in testes, and suggest that at least mGlu5 receptors are present and functionally active in mature human sperm.

Journal of Endocrinology (2001) 170, 71-78

\section{Introduction}

Glutamate, the major excitatory neurotransmitter in the central nervous system (CNS), activates both 'ionotropic' and 'metabotropic' receptors. Ionotropic receptors form membrane ion channels permeable to mono- and divalent cations, whereas metabotropic $(\mathrm{mGlu})$ receptors are coupled to $G$ proteins and regulate the activity of intracellular enzymes, as well as of membrane ion channels (Nakanishi 1992, 1994). mGlu receptors form a family of eight subtypes, subdivided into three groups on the basis of their sequence homology and transduction pathways (Pin \& Duvoisin 1995). Group I includes mGlu1 and -5, which are coupled to inositol phospholipid hydrolysis; group II and group III include mGlu2 and -3 and mGlu4, $-6,-7$ and -8 receptors respectively, which are all negatively coupled to adenylyl cyclase in heterologous expression systems (Pin \& Duvoisin 1995). All mGlu receptor subtypes are expressed in the CNS, where they have been implicated in several aspects of physiology and pathology (Nakanishi 1994, Nicoletti et al. 1996, Conn \& Pin 1997). However, mGlu receptors are also expressed in peripheral organs, as shown by the presence of mGlu4 receptors in taste buds (Chaudhari et al. 1996), and mGlu5 receptors in rat hepatocytes (Storto et al. 2000), human melanocytes (Frati et al. 2000) and in enteric neurones (Liu \& Kirchgessner 2000). Recent evidence indicates that mGlu1 receptors are phosphorylated by the $G$ proteincoupled receptor kinase-type 4 (GRK4) (Sallese et al. 2000), a protein kinase that mediates the homologous 
desensitisation of $G$ protein-coupled receptors and is abundantly expressed in the testis (Sallese et al. 1994, 1997). This prompted us to search for the expression of mGlu receptors in the testis, as well as in other endocrine organs. We now report that distinct mGlu receptor subtypes are present in rat and human testes and that mGlu5 receptors are expressed in mature human sperm.

\section{Materials and Methods}

\section{Materials}

Our studies involving animal experimentation conformed with Guidelines on the Handling and Training of Laboratory Animals, Universities Federation for Animals Welfare at The Old School, Wheathampstead, Herts, UK. Patients were recruited from the University of Catania, Italy and gave their informed consent.

(1S,3R)-1-aminocyclopentane-1,3-dicarboxylic acid (ACPD), 2-methyl-6-(phenyethynyl)-pyridine (MPEP) and 7-hydroxyiminocyclopropa[b]chromen-1a-carboxylic acid ethylester (CPCCOEt) were purchased from Tocris Cookson Ltd (Bristol, UK). All other drugs or chemicals were puchased from Sigma (Milan, Italy).

\section{$R T-P C R$}

Total RNA $(5 \mu \mathrm{g})$ extracted from rat testes or other tissues and $150 \mathrm{ng}$ random hexamers dissolved in $12 \mu \mathrm{l}$ RNAsefree water were heated to $70{ }^{\circ} \mathrm{C}$ for $10 \mathrm{~min}$ and then cooled in ice for $1 \mathrm{~min}$. We then added $7 \mu \mathrm{l}$ Tris $-\mathrm{HCl}$ buffer (20 mM, pH 8.4) containing $\mathrm{KCl}(50 \mathrm{mM})$, $\mathrm{MgCl}_{2}(2.5 \mathrm{mM})$, dNTP $(500 \mu \mathrm{M})$ and dithiothreitol (DTT; $10 \mathrm{mM})$. After $5 \mathrm{~min}$ of incubation at $25^{\circ} \mathrm{C}, 1 \mu \mathrm{l}$ Superscript II (200 U) (Gibco-BRL, Life Technologies, Milan, Italy) was added and the incubation was continued for an additional $10 \mathrm{~min}$ at $25{ }^{\circ} \mathrm{C}$ and then for $50 \mathrm{~min}$ at $42{ }^{\circ} \mathrm{C}$. The reaction was terminated by $15 \mathrm{~min}$ of incubation at $70{ }^{\circ} \mathrm{C}$. After cooling the samples in ice, $1 \mu \mathrm{l}$ RNAse $\mathrm{H}(2 \mathrm{U})$ was added and the samples were incubated at $37^{\circ} \mathrm{C}$ for $20 \mathrm{~min}$. PCR was carried out in $50 \mu \mathrm{l}$ of a Tris- $\mathrm{HCl}$ buffer $(10 \mathrm{mM}, \mathrm{pH} 8.8)$ containing $\mathrm{MgCl}_{2}$ (1.5 mM), KCl (50 mM), Triton X-100 (0.1\%), dTTP, dGTP, dCTP, dATP (200 $\mu \mathrm{M}$ of each), forward and reverse primers ( $25 \mathrm{pM}$ of each) and $1 \mu \mathrm{l}$ single-stranded cDNA. Taq polymerase (1 U) was added in hot-start conditions $\left(94^{\circ} \mathrm{C}\right.$ for $\left.3-5 \mathrm{~min}\right)$ and 30 cycles were carried out as follows: $94{ }^{\circ} \mathrm{C}$ for $1 \mathrm{~min}, 58^{\circ} \mathrm{C}$ for $2 \mathrm{~min}$ and $72{ }^{\circ} \mathrm{C}$ for $3 \mathrm{~min}$. Amplification products were separated by agarose gel $(2 \%)$ and visualised with ethidium bromide. Primers and PCR conditions were as follows.

mGlu1 receptor: accession no. M61099; 1.5 mM $\mathrm{MgCl}_{2}$; annealing at $60{ }^{\circ} \mathrm{C}$; amplimer $207 \mathrm{bp}$; forward:

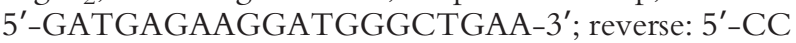
ACCCTCAGGAAGTATTTG-3'
mGlu2 receptor: accession no. M92075; $1.5 \mathrm{mM}$ $\mathrm{MgCl}_{2}$; annealing at $60{ }^{\circ} \mathrm{C}$; amplimer $677 \mathrm{bp}$; forward: 5'-GAGAAGGTGGGCCGTGCCATGAG-3'; reverse: 5'-CGCTGCCTGCCCGCAGATAGGT-3'

mGlu3 receptor: accession no. M92076; $1 \mathrm{mM} \mathrm{MgCl}_{2}$; annealing at $66^{\circ} \mathrm{C}$; amplimer $396 \mathrm{bp}$; forward: $5^{\prime}-\mathrm{GCT}$

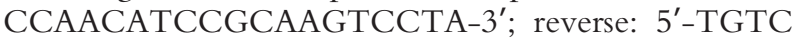
AATGGCCAGGTGCTTGTC-3'

mGlu4 receptor: accession no. M90518; $1 \mathrm{mM} \mathrm{MgCl}_{2}$; annealing at $60{ }^{\circ} \mathrm{C}$; amplimer $409 \mathrm{bp}$; forward: $5^{\prime}$-CCC AGAATGAGAAGAGTACC-3'; reverse: 5'-TCTGCG AAGGTCGTCATGGT -3'

mGlu5 receptor: accession no. D10891; $1.5 \mathrm{mM}$ $\mathrm{MgCl}_{2}$; annealing at $60^{\circ} \mathrm{C}$; amplimer $585 \mathrm{bp}$; forward: 5'-GGCCATTCAAGTCCAGAACT-3'; reverse: 5'-GT GTGAACAGCTGAGACATA-3'

\section{Immunoprecipitation analysis}

Testes removed from male Sprague-Dawley rats (200 \pm 20 g body weight; Charles River, Calco, Italy) were homogenised at $4{ }^{\circ} \mathrm{C}$ in Tris- $\mathrm{HCl}$ buffer $(20 \mathrm{mM}$, $\mathrm{pH} 7 \cdot 4$ ) containing $10 \%$ sucrose, $1 \mathrm{mM}$ phenylmethylsulphonylfluoride, $10 \mu \mathrm{g} / \mathrm{ml}$ leupeptin and $1 \%$ aprotinin. Homogenates were centrifuged at $1500 \mathrm{~g}$ for $20 \mathrm{~min}$ and supernatants were centrifuged twice at $20000 \boldsymbol{g}$ for $30 \mathrm{~min}$. The resulting pellets were resuspended in ice-cold

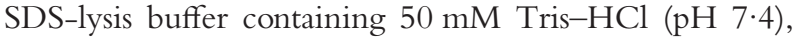
$80 \mathrm{mM} \beta$-glicerophosphate, $20 \mathrm{mM}$ EGTA, $150 \mathrm{mM}$ $\mathrm{NaCl}, 15 \mathrm{mM} \mathrm{MgCl} 2,1 \mathrm{mM}$ DTT, $1 \mu \mathrm{g} / \mathrm{ml}$ aprotinin, $1 \mu \mathrm{g} / \mathrm{ml}$ leupeptin, $0 \cdot 1 \%$ Triton-X 100 and $0 \cdot 2 \%$ SDS, and an aliquot was used for protein determination. Five micrograms of immunoprecipitating antibodies directed against mGlu1, $-2 / 3$ or -5 receptors (see below) were added to $0.5-1 \mathrm{mg}$ membrane extracts and gently mixed overnight at $4{ }^{\circ} \mathrm{C}$ on a rocker shaker. Immunocomplexes were captured by incubation of the extracts for $2 \mathrm{~h}$ with protein A/Sepharose (5 mg/sample). Samples were centrifuged at 14000 r.p.m. and washed three times with $1 \mathrm{ml}$ ice-cold phosphate-buffered saline (PBS). After the last centrifugation at 14000 r.p.m., each sample was re-suspended in SDS-bromophenol blue reducing buffer containing $40 \mathrm{mM}$ DTT, to limit the formation of high molecular weight receptor aggregates. After boiling, samples were centrifuged and supernatants were used for Western blot analysis. Western blots were carried out using 8\% SDS polyacrylamide gels run on a minigel apparatus (Mini Protean II Cell; Bio-Rad, Milan, Italy); gels were electroblotted on ImmunBlot PVDF membrane (BioRad) for $1 \mathrm{~h}$ using a semi-dry electroblotting system (Trans-blot system SD; Bio-Rad), and filters were blocked overnight in TTBS buffer $(100 \mathrm{mM}$ Tris- $\mathrm{HCl}, 0.9 \%$ $\mathrm{NaCl}$ and $0 \cdot 1 \%$ Tween $20, \mathrm{pH} 7 \cdot 4$ ) containing $2 \%$ non-fat dry milk. Blots were then incubated for $1 \mathrm{~h}$ at room temperature with primary polyclonal antibodies $(1 \mu \mathrm{g} / \mathrm{ml})$ which recognise specific carboxy-terminal epitopes of 


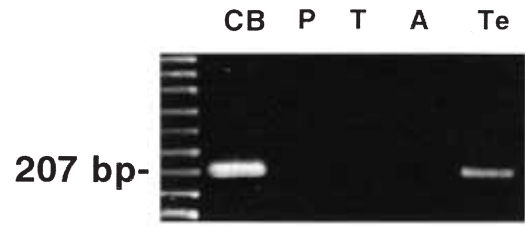

mGlu1

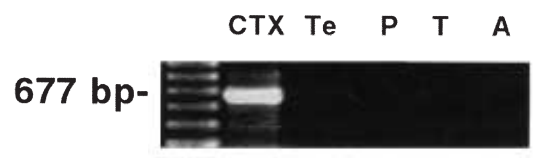

\section{mGlu2}

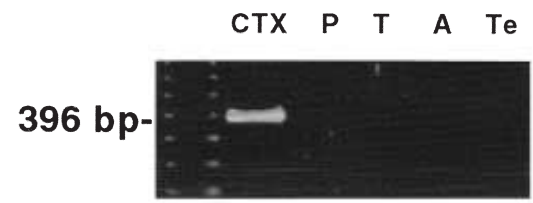

mGlu3

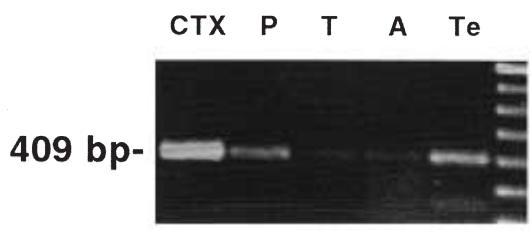

\section{mGlu4}

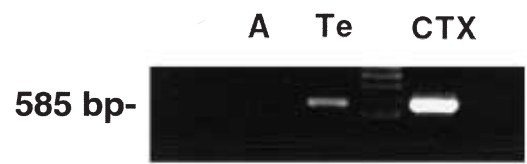

Figure 1 RT-PCR analysis of mGlu1, $-2,-3,-4$ and -5 receptor mRNA in extracts of rat testes (Te), pancreas $(\mathrm{P})$, thyroid $(\mathrm{T})$ and adrenal glands (A). Extracts from rat cerebellum $(\mathrm{CB})$ or cerebral cortex (CTX) were used as positive controls for mGlu1, -2, -3, -4 and -5 receptors respectively.

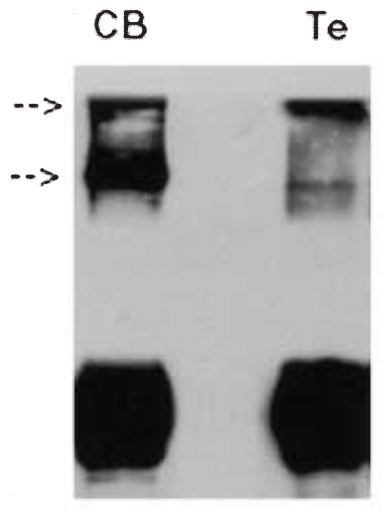

mGlu1

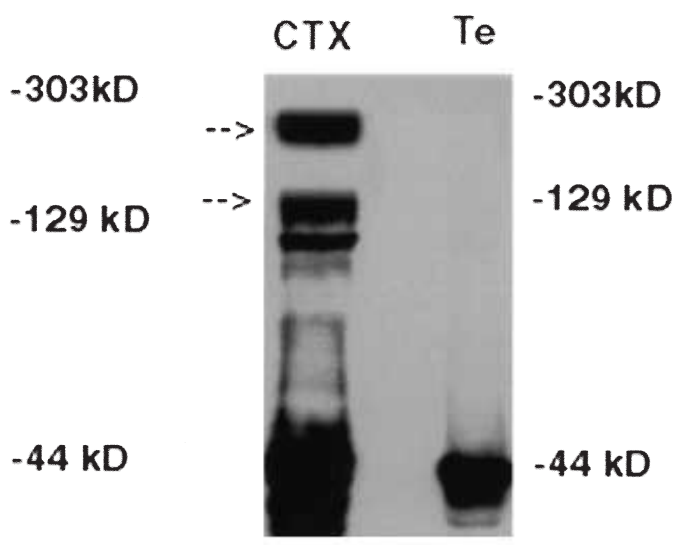

mGlu2/3

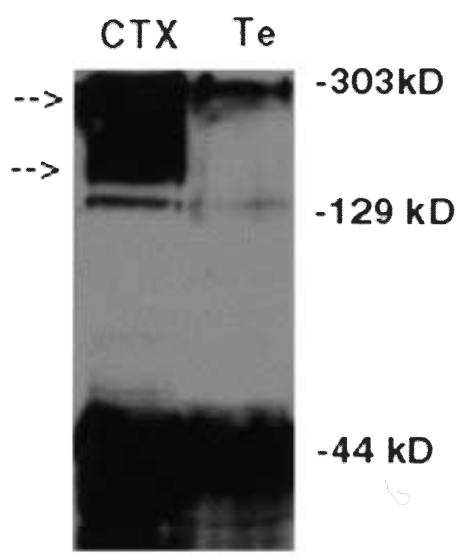

mGlu5

Figure 2 Western blot analysis of mGlu1a, $-2 / 3$ and -5 receptors in immunoprecipitates from rat cerebellum (CB) or cerebral cortex (CTX) and rat testes (Te). Immunoglobulins used for immunoprecipitation are labelled at $46 \mathrm{kDa}$. Arrows point to the monomeric $(140 \mathrm{kDa}$ ) and dimeric forms (above $200 \mathrm{kDa}$ ) of mGlu1a, $-2 / 3$ and -5 receptors and to the right are the molecular standard sizes. 
mGlu5

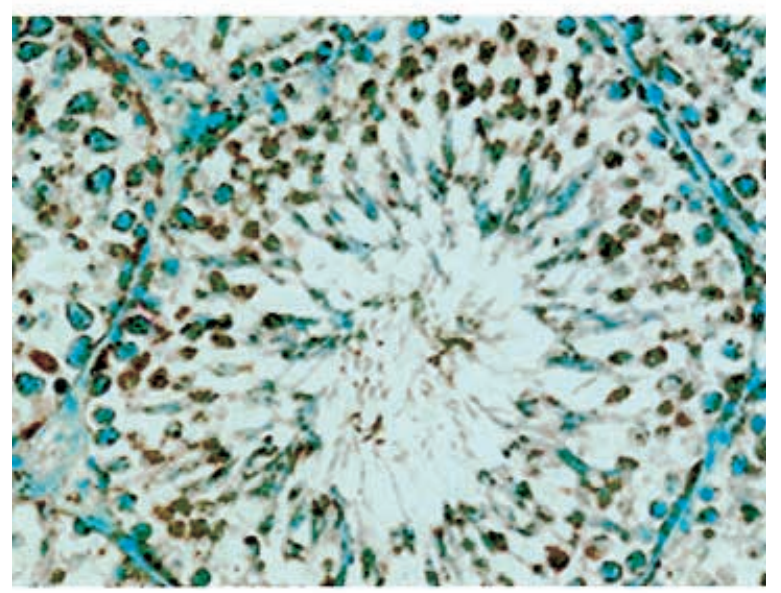

\section{mGlu1}

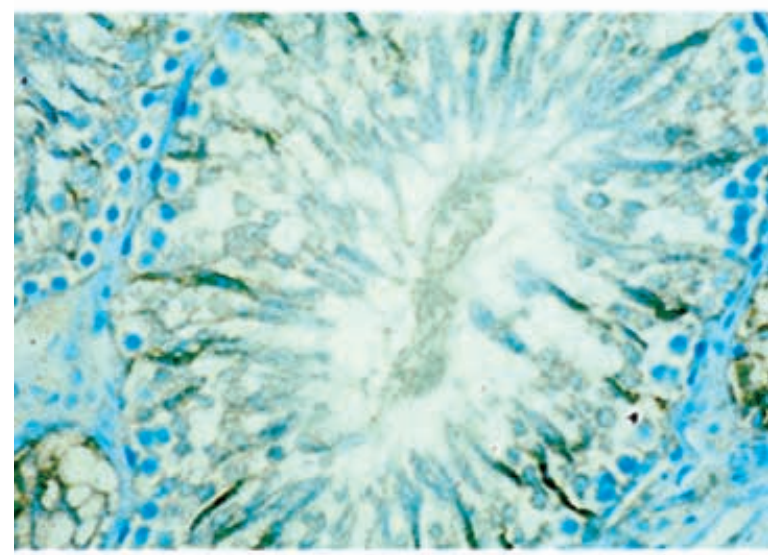

GRK4

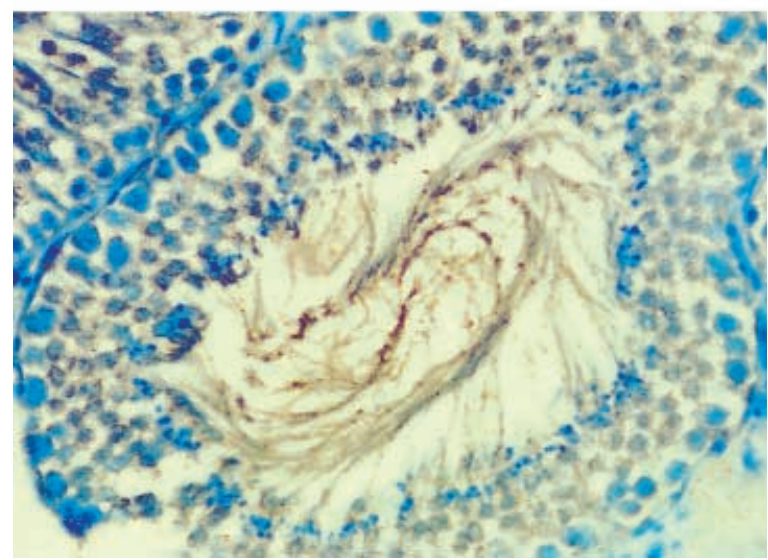

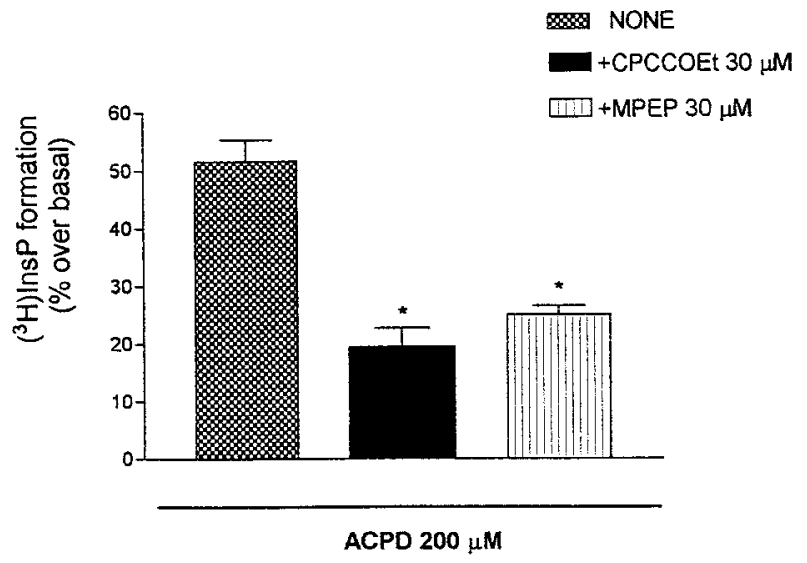

Figure 4 Measurement of inositol phospholipid hydrolysis in slices from rat testes incubated with the mGlu receptor agonist, $1 \mathrm{~S}, 3 \mathrm{R}-\mathrm{ACPD}(200 \mu \mathrm{M})$, in the absence or presence of MPEP $(30 \mu \mathrm{M})$ or CPCCOEt $(30 \mu \mathrm{M})$. Values are means \pm S.E.M. of four to six determinations. ${ }^{*} P<0.05$ (one-way ANOVA+Fisher's PLSD) vs values obtained in the absence of antagonists.

\section{Immunohistochemical analysis of rat and human testes}

Male Sprague-Dawley rats were anaesthetised with nembutal $(40 \mathrm{mg} / \mathrm{kg}$ i.p.) and subjected to intracardiac perfusion with $0 \cdot 1 \mathrm{M}$ PBS, $\mathrm{pH} 7 \cdot 4$ and then with $10 \%$ formalin. Rat testes or human bioptic samples from the testes of patients with normal or arrested spermatogenesis were dissected, post-fixed in 10\% formalin for $24 \mathrm{~h}$ at room temperature, dehydrated and paraffin-embedded. Tissue blocks were cut with a microtome (Ernst Leitz $\mathrm{GmbH}$, Vienna, Austria) and $5 \mu \mathrm{m}$ sections were pretreated with $0.3 \% \mathrm{H}_{2} \mathrm{O}_{2}$ in ethanol at $4{ }^{\circ} \mathrm{C}$ for $15 \mathrm{~min}$ to inhibit endogenous peroxidase activity and washed with PBS $(0 \cdot 1 \mathrm{M}, \mathrm{pH} 7 \cdot 4)$ containing $0 \cdot 05 \%$ Tween 20 . Sections were incubated with $50 \%$ normal goat serum (NGS) for $10 \mathrm{~min}$ at $37^{\circ} \mathrm{C}$ to reduce non-specific immunostaining, and then with mGlu1a $(12 \mu \mathrm{g} / \mathrm{ml})$, mGlu5 $(5 \mu \mathrm{g} / \mathrm{ml})$ or GRK4 (K-20; $1 \mu \mathrm{g} / \mathrm{ml}$; Santa Cruz Biotechnology Inc., Santa Cruz, CA, USA) antibodies in $1 \%$ NGS at $4{ }^{\circ} \mathrm{C}$ overnight. Detection was accomplished using a Vectastain Elite ABC kit (Vector Laboratories, Burlingame, CA, USA). Sections were incubated with an anti-rabbit biotinconjugated IgG (1:100; Calbiochem, La Jolla, CA, USA) in $50 \%$ NGS for $30 \mathrm{~min}$ at room temperature, and finally incubated with the $\mathrm{ABC}$ reagent for $30 \mathrm{~min}$ at room temperature. After each incubation step, sections were carefully washed with PBS $(0 \cdot 1 \mathrm{M}, \mathrm{pH} 7 \cdot 4)$. Immunostaining was revealed using $3,5^{\prime}$-diaminobenzidine

Figure 3 Immunohistochemical analysis of mGlu5 receptors, mGlu1 receptors and GRK4 in sections from rat testes. Note that mGlu5 receptors share the same anatomical localisation as GRK4, whereas mGlu1a receptors are more intensely labelled in Sertoli cells and in the intertubular spaces. Objective $=20$ and $60 \times$ for mGlu $1 \mathrm{a}, 40$ and $60 \times$ for mGlu5 and 20 and $60 \times$ for GRK 4 . 

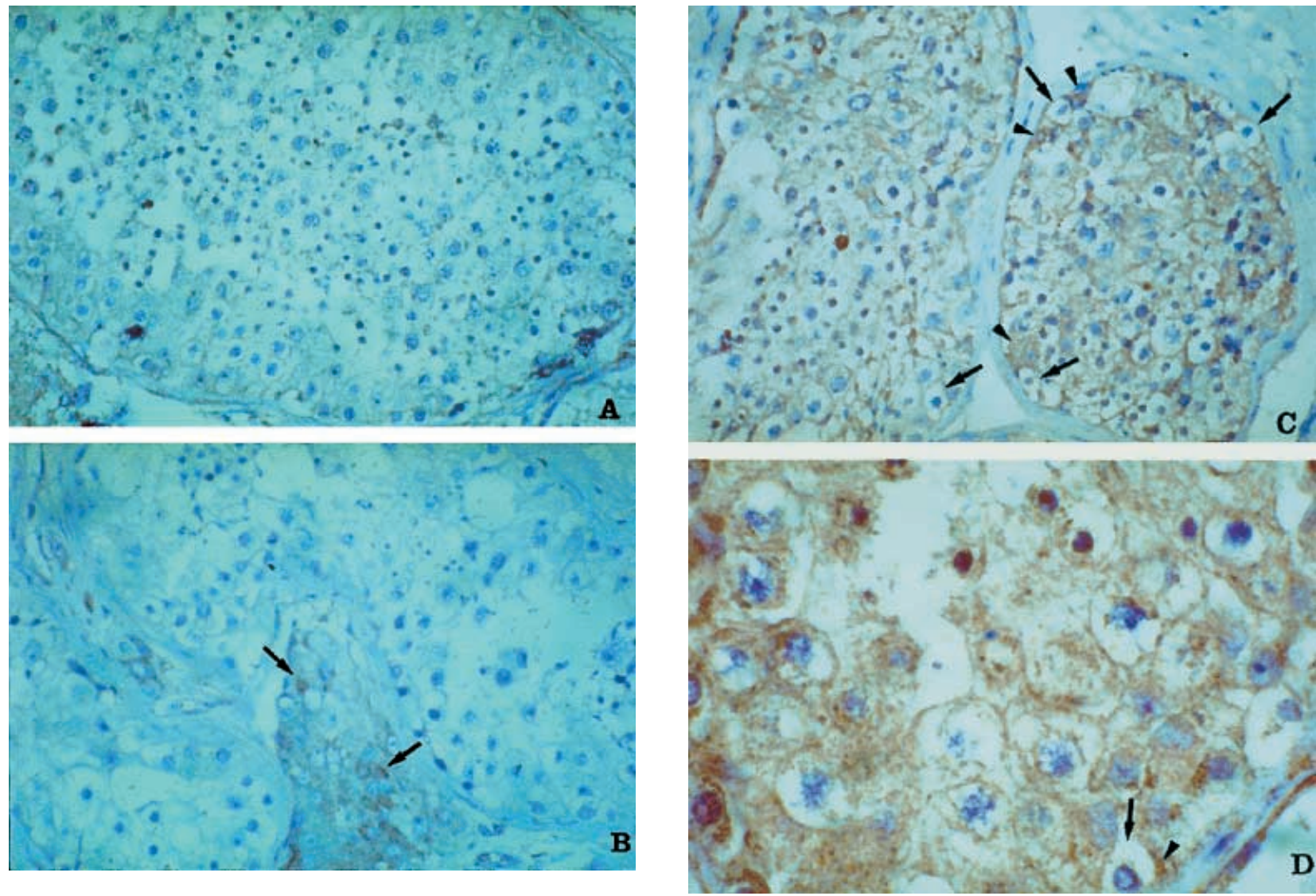

Figure 5 Expression of mGlu1 and -5 receptors in bioptic samples from human testes. (A) mGlu1a immunostaining in the testis from a patient (T G) with varicocele and normal spermatogenesis; note the absence of mGlu1a immunoreactivity inside the tubuli. (B) mGlu1a immunostaining in the testis from a patient $(\mathrm{PG}$ ) with intra-abdominal testicular retention and arrested spermatogenesis; note that only Leydig cells in the intertubular space show cytoplasmic immunostaining (arrows). (C) mGlu5 immunostaining in the testis from a patient (PR) with hydrocele and normal spermatogenesis; note the absence of immunostaining in spermatogonia (arrows) and the presence in Sertoli cells (arrowheads). (D) mGlu5 immunostaining at higher magnification in a testis from a patient (G T) with varicocele and arrested spermatogenesis; arrows point to spermatogonia and arrowheads to Sertoli cells.

$(0 \cdot 04 \%)$ in $0 \cdot 1 \mathrm{M}$ PBS containing $0 \cdot 3 \% \mathrm{H}_{2} \mathrm{O}_{2}$, using as counterstain methylene blue or haematoxylin.

\section{Immunofluorescent analysis of human spermatozoa}

Human spermatozoa from healthy volunteers were washed twice in PBS, smeared on glass slides, air-dried, fixed for $10 \mathrm{~min}$ in methanol at $-20{ }^{\circ} \mathrm{C}$, extracted for $5 \mathrm{~s}$ in acetone at $-20^{\circ} \mathrm{C}$, re-dried, washed three times in PBS, and treated with PBS, 5\% NGS and 1\% BSA for $20 \mathrm{~min}$. Spermatozoa were incubated overnight at $4{ }^{\circ} \mathrm{C}$ in the presence of antibodies directed against mGlu1a $(5 \mu \mathrm{g} / \mathrm{ml})$, mGlu5 $(5 \mu \mathrm{g} / \mathrm{ml}$; Upstate Biotechnology), GRK4 or $\beta$-arrestin $(1 \mu \mathrm{g} / \mathrm{ml} ; \mathrm{N}-19$; Santa Cruz Biotechnology Inc.), then washed three times in PBS containing 0.1\% BSA, and incubated in fluorescein isothiocyanate goat anti-rabbit antibodies (Calbiochem). Finally, the glass slides were washed three times in PBS, mounted in PBS and glycerol (1:10) containing 5\% propylgallate, and observed with a Leitz Aristoplan microscope (E Leitz, Rockleigh, NJ, USA).

\section{Assessment of human sperm motility}

Sperm motility was assessed in aliquots of seminal fluid from healthy human donors. Ninety microlitres of undiluted semen were added to $10 \mu \mathrm{l}$ water, MPEP $(30 \mu \mathrm{M})$ or quisqualate $(100 \mu \mathrm{M})$, and the percentage of motile sperm was recorded for $60 \mathrm{~min}$. The quality of motility was graded 1 to 3 . Spermatozoa with grade 3 motility tend to move rapidly across the field, grade 2 sperm move aimlessly, whereas grade 1 sperm have a beating tail but do not change position. 


\section{Results}

\section{Expression of $m G l u$ receptor subtypes in rat testes}

RT-PCR analysis showed the presence of mGlu1, -4 and -5 , but not mGlu2 or -3 mRNA in the rat testis. mGlu1 and -5 receptor mRNA was absent from other endocrine organs including pancreas, thyroid and adrenal glands (Fig. 1). In contrast, mGlu4 receptor mRNA was also detected in the pancreas (Fig. 1). We extended the analysis to mGlu1 and -5 receptor proteins by using polyclonal antibodies specific for either receptor subtype. It is noteworthy that the mGlu1 antibody recognises an epitope that is exclusively present in the major splice variant of mGlu1 receptors (i.e. the mGlu1a receptor) and therefore does not provide any information on the expression of other mGlu1 splice variants (i.e. mGlu1b to -1 e receptors). Western blot analysis of immunoprecipitates from rat cerebral cortex or cerebellum (used as reference tissues) showed two major bands corresponding to the monomeric and dimeric form of mGlu1a, $-2 / 3$ and -5 receptors (Fig. 2, arrows). mGlu1 and -5 receptors were detected in immunoprecipitates from the rat testis, whereas $m$ Glu $2 / 3$ receptors were absent (Fig. 2). Immunohistochemical analysis of the rat testis showed a high mGlu5 immunoreactivity inside the seminiferous tubuli. Cells of the germinal line were intensely labelled beyond the stage of spermatogonia. This distribution pattern was shared by GRK4 immunoreactivity (Fig. 3). mGlu1a immunoreactivity inside the seminiferous tubuli was less intense in germinal cells, but was particularly pronounced in Sertoli cells. An intense mGlu1a immunostaining was noted in the intertubular spaces (Fig. 3).

To assess whether the mGluR1 and -5 receptors expressed in rat testes are functionally coupled to a $\mathrm{Gq}$ protein-mediated second messenger response, we measured the stimulation of inositol phospholipid hydrolysis in slices from rat testes challenged with the mGlu receptor agonist, 1S,3R-ACPD. Exposure to $200 \mu \mathrm{M}$ 1S,3R-ACPD for $60 \mathrm{~min}$ induced a significant increase in the accumulation of $\left[{ }^{3} \mathrm{H}\right] \mathrm{Ins} \mathrm{P}$. This increase was reduced by about $50 \%$ by saturating concentrations of either CPCCOEt $(30 \mu \mathrm{M})$ or MPEP $(30 \mu \mathrm{M})$ (Fig. 4), which behave as selective and non-competitive mGlu1 and -5 receptor antagonists respectively (Annoura et al. 1996, Gasparini et al. 1999, Litschig et al. 1999). These results indicate that mGluR 1 and -5 receptors are coupled to inositol phospholipid hydrolysis in rat testes.

\section{Expression of $m G l u$ receptors in human testes}

To assess whether mGlu receptors are present in human testes, we examined the expression of mGlu1 and -5 receptors by immunocytochemistry in tissue specimens from adult patients who underwent testicular biopsy. Two of these patients ( $\mathrm{T} \mathrm{G}$ and $\mathrm{G} \mathrm{T}$ of 21 and 28 years of age respectively) had bilateral varicocele. Spermatogenesis was normal in T G and arrested in G T. Another patient (P R, 23 years of age) had left hydrocele with normal spermatogenesis. The last patient (P G) had an intra-abdominal testicular retention that had remained untreated until 37 years of age. This patient was sterile. All patients gave informed consent to the study. Immunohistochemical analysis showed the absence of mGlu1a receptor immunoreactivity inside the seminiferous tubuli and its presence in the intertubular space in bioptic samples from all patients, regardless of the pathological condition (see Fig. 5A and B). In contrast, the seminiferous tubuli of all patients (with normal or abnormal spermatogenesis) were heavily labelled with mGlu5 antibodies. The labelling was apparently present in all cells of the germinal line with the exception of large rounded spermatogonia (see arrows in Fig. 5C and D); Sertoli cells were also immunopositive for mGlu5 receptors (arrowheads in Fig. 5C and D). Thus, while the cellular localisation of the mGlu5 receptor in the human testis was similar to that observed in the rat testis, a difference existed between the expression patterns of mGlu1a receptors in the two species.

\section{Expression of $m G l u$ receptors in human sperm}

We performed fluorescent microscopy analysis of human mature spermatozoa to examine the localisation of mGlu1 or -5 receptors in these cells. Immunofluorescent analysis of mGlu1a receptors did not show any positive immunostaining in mature spermatozoa (not shown), consistent with the lack of mGlu1a receptor immunoreactivity in the seminiferous tubuli of human testes. In contrast, mGlu5 receptors were positively labelled in mature sperm, where they were predominantly localised in the mid-piece and tail. mGlu5 receptor immunoreactivity was observed below the acrosomal region in the head of spermatozoa. No labelling of the acrosome region was ever observed (Fig. 6a). The mGlu5 receptor was only partially co-localised with the receptor kinase GRK4, which was expressed in the mid-piece, but was particularly abundant in the acrosome (Fig. 6b). In contrast, a high degree of co-localisation was found between mGlu5 receptors and $\beta$-arrestin (Fig. 6c), a protein that is known to interact with the $G$ protein-coupled receptors in the regulation of receptor signalling.

To examine the possibility that activation of mGlu5 receptors could affect sperm motility, we measured the percentage of motile sperms in aliquots of the seminal fluid from healthy human volunteers treated with $100 \mu \mathrm{M}$ quisqualate (a potent agonist of $\mathrm{mGlu} 1$ and -5 receptors) or with $30 \mu \mathrm{M}$ of the mGlu5 receptor antagonist, MPEP. None of these drugs induced changes in the total percentage of motile spermatozoa, nor in the grading of sperm motility (not shown). 

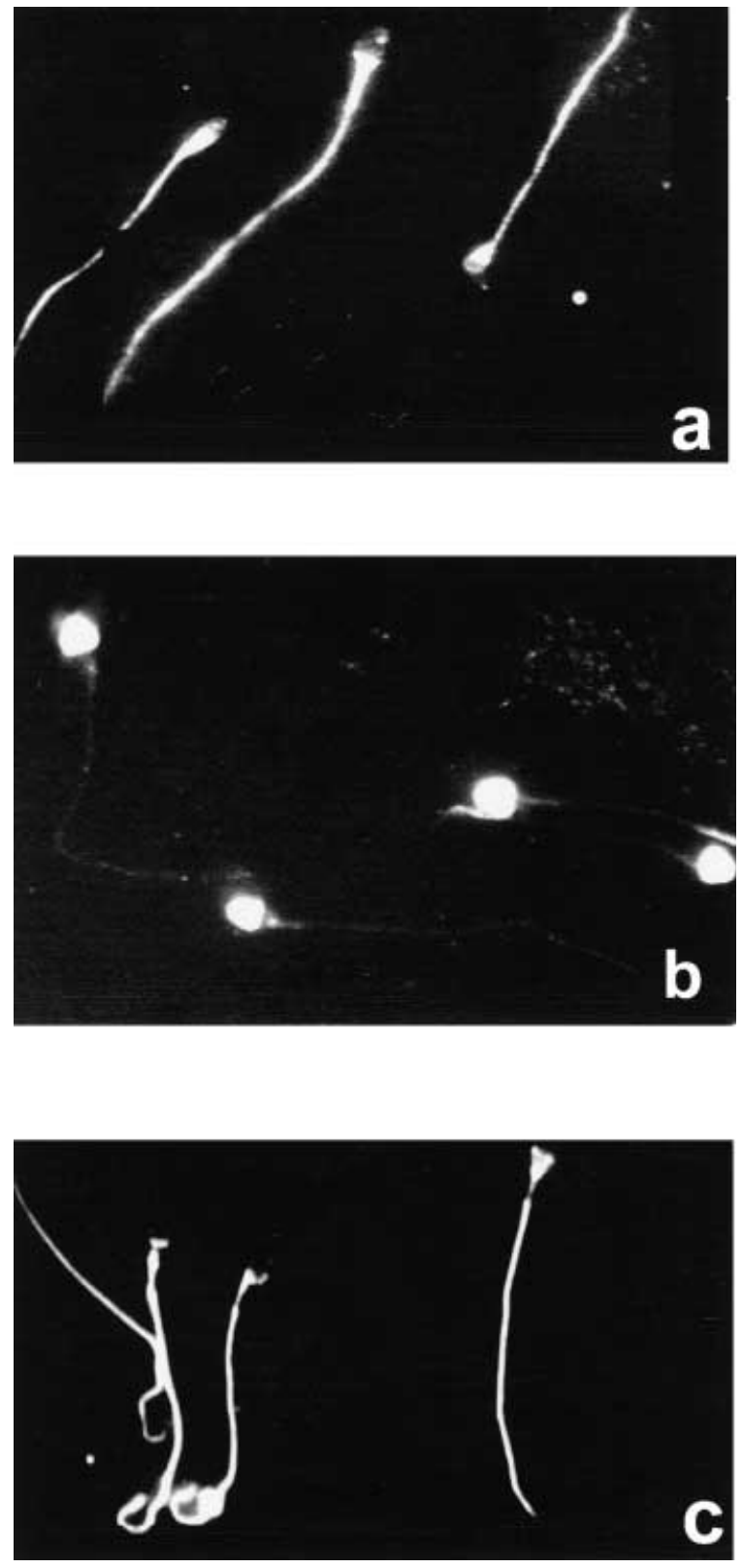

Figure 6 Fluorescent microscopy analysis of (a) mGlu5 receptors, (b) GRK4 and (c) $\beta$-arrestin in human spermatozoa.

\section{Discussion}

We moved from the observation that GRK4 mediates the homologous desensitisation of mGlu1 receptors. GRK4 is co-localised with mGlu1 receptors in cerebellar Purkinje cells, and translocates in response to mGlu1 receptor activation; in addition, GRK4 phosphorylates and desensitises mGlu1 receptors in heterologous expression systems (Sallese et al. 2000). Hence, we decided to examine whether mGlu1 or other mGlu receptor subtypes are present in the testis, where GRK4 shows the highest levels of expression (Sallese et al. 1994). mGlu1 and -5 receptors were both expressed in rat testes with a high degree of specificity because their transcript was absent in other endocrine organs, including the adrenals which can also synthesise steroid hormones. Germinal cells of rat testes were immunopositive not only for mGlu1 and -5 receptors, but also for GRK4, a kinase that regulates receptor signalling. This suggests that mGlu1 and -5 receptors are functional in rat testes. Accordingly, the mGlu1/5 receptor agonist, $1 \mathrm{~S}, 3 \mathrm{R}-\mathrm{ACPD}$, was able to stimulate inositol phospholipid hydrolysis in slices prepared from rat testes. The use of CPCCOEt and MPEP confirmed that stimulation of inositol phospholipid hydrolysis resulted from the activation of both mGlu1 and -5 receptors. In fact, CPCCOEt and MPEP behave as potent and highly selective non-competitive antagonists of mGlu1 and -5 receptors respectively (Annoura et al. 1996, Gasparini et al. 1999, Litschig et al. 1999). The distribution pattern between rat and human testes was similar for mGlu5 receptors, but divergent with respect to mGlu1a receptors. In human testes, mGlu5 immunolabelling was intense inside the seminiferous tubuli, whereas mGlu1a immunolabelling was detected in Leydig cells of intertubular spaces. The hypothesis that mGlu1a receptors regulate the function of Leydig cells is intriguing. Studies on glutamate receptor activation and testosterone production are still lacking, although D-aspartate (a structural analogue of glutamate) has proved to stimulate testosterone synthesis in isolated rat Leydig cells (Nagata et al. 1999).

The high expression of mGlu5 receptors in the seminiferous tubuli raises the possibility that these receptors regulate the maturation of germinal cells (perhaps after the stage of spermatogonia) or are needed for the physiology of mature spermatozoa. As opposed to mGlu1 receptors, mGlu5 receptors produce oscillatory increases in intracellular $\mathrm{Ca}^{2+}$ when activated in heterologous expression systems (Kawabata et al. 1996). Hence, mGlu5 receptors have the potential to generate intracellular $\mathrm{Ca}^{2+}$ waves in cells of the germinal line, including mature spermatozoa. mGlu5 receptors were predominantly localised in the mid-piece and tail of human sperm, whereas GRK4 was mostly present in the acrosome and mid-piece. However, the localisation of mGlu5 receptors coincided with that of $\beta$-arrestin, a functional cofactor of GRKs, which acts as a major determinant in the homologous desensitisation and internalisation of $\mathrm{G}$ protein-coupled receptors (Krupnick \& Benovic 1998, Lefkowitz 1998, Iacovelli et al. 1999). This particular localisation suggested that mGlu5 receptors could be active in regulating sperm motility. Although mGlu5 receptor agonists or antagonists were unable to induce substantial changes in the percentage of motile sperm, such an action cannot be entirely ruled out because mGlu5 receptors have a significant constitutive activity, 
and may therefore be active in the absence of any ligand (see Pin \& Duvoisin 1995).

In conclusion, these results provide the first evidence that any glutamate receptor is expressed in rat and human testes or human sperm. Understanding the mechanism of activation and the functional role of mGlu receptors might disclose novel aspects in the physiology and pathophysiology of the male reproductive system.

\section{Acknowledgement}

We are grateful for the financial support of Telethon-Italy (grant no. 1238).

\section{References}

Annoura H, Fukunaga A, Uesugi M, Tatsuoka T \& Horikawa Y 1996 A novel class of antagonists for metabotropic glutamate receptors, 7-(hydroxyimino)cyclopropa[b]chromen-1a-carboxylates. Bioorganic and Medicinal Chemistry Letters 6 763-766.

Chaudhari N, Yang H, Lamp C, Delay E, Cartford C, Than T \& Roper S 1996 The taste of monosodium glutamate: membrane receptors in taste buds. Journal of Neuroscience 16 3817-3826.

Conn PJ \& Pin JP 1997 Pharmacology and functions of metabotropic glutamate receptors. Annual Reviews of Pharmacology and Toxicology 37 205-237.

Frati C, Marchese C, Fisichella G, Copani A, Nasca MR, Storto M \& Nicoletti F 2000 Expression of functional mGlu5 metabotropic glutamate receptors in human melanocytes. Journal of Cellular Physiology 183 364-372.

Gasparini F, Lingenhöhl K, Stoehr N, Flor PJ, Heinrich M, Vranesic I, Biollaz M, Allgeirer H, Heckendorn R, Urwyler S, Varney MA, Johnson EC, Hess SD, Rao SP, Sacaan AI, Santori EM, Veliçelebi G \& Kuhn R 1999 2-Methyl-6-(phenylethynyl)-pyridine (MPEP), a potent, selective and systemically active mGlu5 receptor antagonist. Neuropharmacology 38 1493-1503.

Iacovelli L, Sallese M, Mariggio' S \& De Blasi A 1999 Regulation of G-protein coupled receptor kinase subtypes by calcium sensor protein. FASEB Journal 13 1-8.

Kawabata S, Tsutsumi R, Kohara A, Yamaguchi T, Najanishi S \& Okada M 1996 Control of calcium oscillation by phosphorylation of metabotropic glutamate receptors. Nature 383 89-92.
Krupnick JG \& Benovic JL 1998 The role of receptor kinase and arrestins in $\mathrm{G}$ protein-coupled receptor regulation. Annual Reviews of Pharmacology and Toxicology 38 289-310.

Lefkowitz RJ 1998 New roles for receptor kinase and beta-arrestins in receptor signaling and desensitization. Journal of Biological Chemistry 273 18677-18680.

Litschig S, Gasparini F, Ruegg D, Stoehr N, Flor PJ, Vranesic I, Prezeau L, Pin J-P, Thomsen C \& Kuhn R 1999 CPCCOEt, a non-competitive mGluR1 antagonist, inhibits receptor signaling without affecting glutamate binding. Molecular Pharmacology $\mathbf{5 5}$ 453-461.

Liu M \& Kirchgessner AL 2000 Agonist-and reflex-evoked internalization of metabotropic glutamate receptor 5 in enteric neurons. Journal of Neuroscience 20 3200-3205.

Nagata Y, Homma H, Matsumoto M \& Imai K 1999 Stimulation of steroidogenic acute regulatory protein (StAR) gene expression by D-aspartate in rat Leydig cells. FEBS Letters 454 317-320.

Nakanishi S 1992 Molecular diversity of glutamate receptors and implications for brain function. Science 258 597-602.

Nakanishi S 1994 Metabotropic glutamate receptors: synaptic transmission, modulation and plasticity. Neuron 13 1031-1037.

Nicoletti F, Iadarola MJ, Wroblewski JT \& Costa E 1986 Excitatory amino acid recognition sites coupled with inositol phospholipid metabolism: developmental changes and interaction with a1-adrenoceptors. PNAS 83 1931-1935.

Nicoletti F, Bruno V, Copani A, Casabona G \& Knopfel T 1996 Metabotropic glutamate receptors: a new target for the therapy of neurodegenerative disorder. Trends in Neuroscience 19 267-271.

Pin JP \& Duvoisin R 1995 The metabotropic glutamate receptors: structure and functions. Neuropharmacology 34 1-26.

Sallese M, Lombardi MS \& De Blasi A 1994 Two isoforms of G protein-coupled receptor kinase 4 identified by molecular cloning. Biochemical and Biophysical Research Communications 1999 848-854.

Sallese M, Mariggio' S, Collodel G, Moretti E, Piomboni P, Baccetti B \& De Blasi A 1997 G protein-coupled receptor kinase GRK4. Journal of Biological Chemistry 272 10188-10195.

Sallese M, Salvatore L, D’Urabano E, Storto M, Nicoletti F, Knopfel T \& De Blasi A 2000 The G-protein coupled receptor kinase GRK4 regulates metabotropic glutamate receptor signaling in cerebellar Purkinje cells. FASEB Journal 14 2569-2580.

Storto M, de Grazia U, Knöpfel T, Canonico PL, Copani A, Richelmi P, Nicoletti F \& Vairetti M 2000 Selective blockade of mGluR 5 metabotropic glutamate receptors protects rat hepatocytes against hypoxic damage. Hepatology 31 649-655.

Received in final form 23 February 2001

Accepted 19 March 2001 